\title{
Faktor-Faktor yang Berhubungan dengan Tekanan Darah pada Masa Pandemi Covid-19
}

\author{
Widiharti $^{1 *}$, Wiwik widiyawati ${ }^{2}$, Widya Lita Fitrianur ${ }^{3}$ \\ ${ }^{1}$ widiharti@umg.ac.id*,2wiwikwidiyawati@umg.ac.id, ${ }^{3}$ widyalita.fitrianur@umg.ac.id \\ ${ }_{1,2,3}$ program studi profesi ners universitas muhammadiyah gresik \\ * corresponding author
}

Informasi artikel
Received: $05-10-2020$
Revised: 09-11-2020
Accepted: $27-11-2020$

\section{Kata kunci:}

keanekaragaman, manifestasi klinis, Coronavirus disease (COVID-19), SARS CoV-2 \begin{abstract}
ABSTRAK
Tekanan darah adalah faktor penting dalam sistem sirkulasi tubuh manusia. Tekanan darah dapat dengan mudah berubah meski dalam hitungan detik. Pada 2 Maret 2020, pemerintah Indonesia pertama kali mengumumkan dua kasus pasien postif Covid-19. Pasien tidak berani melakukan pemeriksaan ke rumah sakit, sehingga jika ada keluhan yang tidak begitu berat mereka akan membeli obat di apotik tanpa mengetahui tekanan darahnya. Hal ini sangat mengkhawatirkan karena tekanan darah yang tidak terkontrol dapat menyebabkan komplikasi lain seperti stroke. Tujuan penelitian menganalisis faktor yang berhubungan dengan tekanan darah.. Desain penelitian analitik observasional, dengan pendekatan Cross Sectional. Pelaksanaan bulan Maret - Mei 2020. Populasi dari Seluruh warga babatan RT 8 RW 2 Kelurahan Babatan Kecamatan Wiyung sebanyak 110 orang. Teknik Sampel total sampling. Variabel independen; jenis kelamin, beban kerja, pendapatan, tingkat kecemasan dan riwayat keluarga. Variabel dependen; tekanan darah. Instrument penelitian; timbangan injak digital, tensi digital, dan kuesioner. Variabel Tingkat kecemasan menggunakan HARS (Hamilton Anxiety Rating Scale). Dianalisis uji statistik Chi Square dengan nilai $p$ value $<0.05$. Hasil penelitian dengan menggunakan uji chi square pada variabel beban kerja nilai $p$-value $0,004<0,005$ ada hubungan beban kerja dengan tekanan darah. Hasil p - value $0,002<0,05$ ada hubungan antara jenis kelamin dengan tekanan darah. Hasil $p$ value $0,463<0,05$ tidak ada hubungan antara tingkat kecemasan, hasilnya $\mathrm{p}$ - value $0,000<0,05$ ada hubungan riwayat keluarga dengan tekanan darah dengan hasil $p$-value $0,000<0,005$. Kesimpulan faktor yang berhubungan dengan tekanan darah yaitu jenis kelamin, beban kerja, pendapatan, riwayat keluarga sedangkan faktor yang tidak berhubungan dengan tekanan darah yaitu kecemasan
\end{abstract}

Key word:

Diversity, Symptoms, COVID-19, SARS CoV-2

\begin{abstract}
Blood pressure is an important factor in the circulatory system of the human body. Blood pressure can easily change even in seconds. On March 2, 2020, the Indonesian government for the first time announced two cases of positive Covid-19 patients. Patients do not dare to go to the hospital for examination, so if there are complaints that are not so severe they will buy medicine at the pharmacy without knowing the blood pressure. This is very worrying because uncontrolled blood pressure can lead to other complications such as stroke. The research objective was to analyze factors associated with blood pressure. Observational analytic research design, with a cross sectional approach. Implementation in March - May 2020. The population of all residents of Babatan RT 8 RW 2, Babatan Village, Wiyung District is 110 people. Total sampling technique. Independent variable; gender, work load, income, level of anxiety and family history. Dependent variable; blood pressure. Research instrument; digital trampling scales, digital tension, and questionnaires. The variable anxiety level uses HARS (Hamilton Anxiety Rating Scale). Chi Square statistical test was analyzed with $\mathrm{p}$ value $<0.05$. The results of the
\end{abstract}


chi square study workload p-value $0.004<0.005$, there is a relationship between workload and blood pressure. The result of $\mathrm{p}$ - value 0.002 $<0.05$, there is a relationship between gender and blood pressure. The result of $\mathrm{p}$ value $0.463<0.05$, there is no relationship between the level of anxiety, the result is p-value $0.000<0.05$, there is a relationship between family history and blood pressure. In conclusion, the factors related to blood pressure are gender, workload, income, family history, while the factors that are not related to blood pressure are anxiety.

\section{Pendahuluan}

Tekanan darah adalah faktor penting dalam sistem sirkulasi tubuh manusia. Banyak foktor yang berpengaruh terhadap peningkatan tekanan darah. Faktor yang mempengaruhi tekanan darah yaitu usia, olah raga, stress, ras, obesitas, jenis kelamin, medikasi (Kozier, 2010). Tekanan darah dapat dengan mudah berubah meski dalam hitungan detik, ditandai dengan pusing, sakit kepala, leher terasa kaku, dan mata berkunang-kunang. Hal ini jelas akan mempengaruhi aktivitas sehari-hari (Sasmalinda, Syafriandi, \& Helma, 2013). Kondisi seseorang dapat dilihat dari perubahan tekanan darah. Seiring dengan peningkatan usia seseorang, tekanan darah juga dapat berubah. Misalnya pada usia lansia sering terjadi peningkatan tekanan darah walaupun ini tidak dianggap sebagai kondisi yang diinginkan (Fadlilah, Rahil, \& Lanni, 2020).

Tekanan darah sistolik bagi orang dewasa (20 tahun) adalah sekitar $115 \mathrm{mmHg}$ sampai $120 \mathrm{mmHg}$ dan tekanan darah diastolik rata-rata $75 \mathrm{mmHg}$ samapi 80 mmHg (Suprayitno, 2019). Salah satu tanda terjadinya masalah sirkulasi adalah tekanan darah yang lebih tinggi dari normal disebut dengan hipertensi Faktor yang mempengruhinya yaitu usia, stress, ras, obesitas, jenis kelamin, medikasi, variasi diurnal, proses penyakit dan olah raga (Kozier, 2010).

Data World Health Organization (WHO) pada tahun 2015 menunjukkan sekitar 1.13 Miliar orang di dunia mengalami hipertensi. Artinya sekitar 1 dari 3 orang di dunia terdiagnosis hipertensi tetapi banyak yang tidak menyadari karena beberapa orang tidak memiliki gejala. Banyak faktor yang dapat mempengaruhi peningkatan tekanan darah, salah satunya adalah kondisi pandemi virus Covid-19. Data temuan pasien Covid-19 di Indonesia adalah mereka yang paling banyak menderita hipertensi (Hartono, 2020).

Pada 2 Maret 2020, pemerintah Indonesia pertama kali mengumumkan dua kasus pasien postif Covid-19. Menurut pakar epidemiologi, identifikasi kasus tersebut merupakan transmisi lokal yang sangat mungkin masuk melalui pintu-pintu gerbang di beberapa wilayah indonesia, salah satunya di Surabaya (Pranita, 2020). Pada masa pandemi Covid-19, banyak orang yang merasa khawatir tentang kondisi yang terjadi setelah Surabaya masuk pada kategori Zona Merah. Dampak yang ditimbulkan dari kondisi tersebut juga sangat mempengaruhi kehidupan masyarakat.

Semenjak dikategorikan sebagai Zona Merah, ekonomi di Surabaya juga terkena dampaknya. Dampak yang paling besar adalah usaha mikro kecil dan menengah (UMKM) serta sektor jasa yakni hotel dan restoran. Akibatnya banyak pegawai atau pekerja yang dirumahkan bahkan terkena pemutusan hubungan kerja (PHK). Hal ini ikut menambah jumlah pengangguran, padahal biaya hidup juga terus meningkat (Afriyadi, 2020). Selain ekonomi, bidang kesehatan juga ikut terdampak akibat covid-19. Rumah sakit mulai fokus menangani pasien terkonfirmasi Covid-19 sehingga beberapa kasus lain seperti hipertensi tidak bisa tertangani dengan baik karena takut akan tertular (Marzuki, 2020). Pasien tidak berani melakukan pemeriksaan ke rumah sakit, sehingga jika ada keluhan yang tidak begitu berat mereka akan membeli obat di apotik tanpa mengetahui tekanan darahnya (Suprayitno \& Wahid, 2019). Hal ini sangat mengkhawatirkan karena tekanan darah yang tidak terkontrol dapat menyebabkan kompikasi lain seperti stroke (Suprayitno \& Huzaimah, 2020)

Berdasarkan uraian diatas, peneliti tertarik untuk melakukan penelitian faktor 
yang berhubungan dengan peningkatan tekanan darah di RT 8 RW 2, kelurahan Babatan kecamatan wiyung Surabaya. Faktor yang ingin ditelliti yaitu jenis kelamin, beban kerja, pendapatan, kecemasan, dan riwayat keluarga terdekat yang memiliki hipertensi.

\section{Metode Penelitian}

Desain penelitian yang digunakan adalah analitik observasional, dengan tujuan meneliti hubungan antar variabel tanpa melakukan manipulasi apapun, dengan pendekatan Cross Sectional (Notoatmodjo, 2012). Penellitian ini dilaksanakan pada bulan maret - mei 2020. Populasi diambil dari Seluruh warga babatan RT 8 RW 2 Kelurahan Babatan Kecamatan Wiyung sebanyak 110 orang. Teknik Pengambilan Sampel Penelitian ini menggunakan teknik total sampling, sehingga jumlah sampel dalam penelitian ini adalah 110 orang. Variabel independen dalam penelitian ini adalah jenis kelamin, beban kerja, pendapatan, tingkat kecemasan dan riwayat keluarga. Variabel dependen dalam penelitian ini adalah tekanan darah. Instrument penelitian adalah timbangan injak digital, tensi digital,dan kuesioner. Variabel Tingkat kecemasan menggunakan HARS (Hamilton Anxiety Rating Scale) (Maier, Buller, Philipp, $\&$ Heuser, 1988). Setiap data akan dianalisis menggunakan uji statistik Chi Square dengan nilai $p$ value $<0.05$.

\section{Hasil dan pembahasan}

\section{1) Karakteristik Demografi}

Karakteristik demografi responden diuraikan dalam bentuk data jenis kelamin, tingkat pendidikan, status pekerjaan, lama bekerja, beban kerja, tingkat kecemasan, sumber informasi, dan tekanan darah.

Tabel 1 Karakteristik demografi responden berdasarkan jenis kelamin, tingkat pendidikan, status pekerjaan, lama bekerja, beban kerja, tingkat kecemasan, sumber informasi dan riwayat keluarga.

\begin{tabular}{lllcc}
\hline $\mathbf{N}$ & \multicolumn{2}{l}{ Karakteristik Responden } & F & \% \\
\hline o & & & & \\
\hline 1 & Jenis & Laki - laki & 35 & 31,8 \\
& kelamin & Perempuan & 75 & 68,2 \\
& Total & & 110 & 100 \\
\hline 2 & Tingkat & Rendah & 79 & 71,8 \\
& Pendidikan & Tinggi & 31 & 28,2 \\
& Total & & 110 & 100 \\
\hline 3 & Status & Tidak & 53 & 48,1 \\
& Pekerjaan & bekerja & & \\
& & Bekerja & 57 & 51,9
\end{tabular}

\begin{tabular}{|c|c|c|c|c|}
\hline \multirow{2}{*}{$\begin{array}{l}\mathbf{N} \\
\mathbf{0}\end{array}$} & \multicolumn{2}{|c|}{ Karakteristik Responden } & \multirow[b]{2}{*}{10} & \multirow{2}{*}{$\begin{array}{c}\text { \% } \\
100 \\
\end{array}$} \\
\hline & Total & & & \\
\hline \multirow[t]{3}{*}{4} & Lama & $<8$ jam & 25 & 22,7 \\
\hline & bekerja & $>8$ & 85 & 77,3 \\
\hline & Total & & 110 & 100 \\
\hline \multirow[t]{3}{*}{5} & Beban kerja & Sedang & 53 & 48,1 \\
\hline & & & 57 & 51,9 \\
\hline & Total & & 110 & 100 \\
\hline \multirow[t]{3}{*}{6} & $\begin{array}{l}\text { Tingkat } \\
\text { kecemasan }\end{array}$ & $\begin{array}{l}\text { Tidak } \\
\text { cemas }\end{array}$ & 36 & 32,7 \\
\hline & & Cemas & 74 & 67,3 \\
\hline & Total & & 110 & 100 \\
\hline \multirow[t]{3}{*}{7} & $\begin{array}{l}\text { Sumber } \\
\text { informasi }\end{array}$ & $\begin{array}{l}\text { Petugas } \\
\text { kesehatan }\end{array}$ & 79 & 71,8 \\
\hline & & $\begin{array}{l}\text { Media } \\
\text { cetak/ } \\
\text { elektronik }\end{array}$ & 31 & 28,2 \\
\hline & Total & & 110 & 100 \\
\hline \multirow[t]{3}{*}{8} & $\begin{array}{l}\text { Riwayat } \\
\text { Keluaroa }\end{array}$ & HT & 69 & 62,7 \\
\hline & & $\begin{array}{l}\text { Tidak } \\
\text { Hipertensi }\end{array}$ & 41 & 37,3 \\
\hline & Total & & 110 & 100 \\
\hline
\end{tabular}

Tabel 1 menunjukkan bahwa sebagian besar warga berjenis kelamin perempuan $(68,2 \%)$, tingkat pendidikan rendah $(71,8 \%)$, lama bekerja $>8$ jam $(77,3 \%)$, kecemasan warga cemas $(67,3 \%)$, sumber informasi petugas kesehatan $(71,8)$, memiliki riwayat keluarga dengan hipertensi $(62,7 \%)$

Tabel 2. Hasil observasi BB dan Tekanan darah

\begin{tabular}{lllll}
\hline No & \multicolumn{2}{c}{ Karakteristik } & F & $\%$ \\
\hline \multirow{2}{*}{ 1. } & $\begin{array}{l}\text { Tekanan } \\
\text { darah }\end{array}$ & Normal & 42 & 38,2 \\
\hline 2. & $\begin{array}{l}\text { Berat } \\
\text { Badan }\end{array}$ & Mean & 53,6 & \\
\hline
\end{tabular}

Tabel 2 menunjukkan hasil sebanyak 68 $(61,8 \%)$ warga memiliki tekanan darah tidak normal, hal ini menunjukkan bahwa warga beresiko mengalami hipertensi jika tidak dilakukan pencegahan dengan baik dan benar. Berat Badan warga rata - rata 53,68 $\mathrm{kg}$. Hal ini menunjukkan bahwa sebagian besar warga memiliki risiko terjadinya peningkatan tekanan darah dilihat dari Berat Badan. Berat badan merupakan salah satu faktor risiko terjadinya peningkatan tekanan darah. Berat badan merupakan faktor risiko yang dapat diubah untuk mencegah terjadinya hipertensi (Rohkuswara \& Syarif, 2017).

\section{Analisis Bivariat}

Hubungan jenis kelamin, beban kerja, tingkat kecemasan dan riwayat keluarga 
dengan tekanan darah. akan dibahas pada

tabel di bawah ini.

Tabel 3 Hubungan jenis kelamin, beban kerja, tingkat kecemasan dan riwayat keluarga dengan tekanan darah di RT 8 RW 2 Kelurahan Babatan Kec Wiyung Bulan Mei 2020.

\begin{tabular}{|c|c|c|c|c|c|c|c|}
\hline \multirow{3}{*}{ No } & \multirow{3}{*}{ Beban Kerja } & \multicolumn{4}{|c|}{ Tekanan Darah } & \multirow{2}{*}{\multicolumn{2}{|c|}{ Total }} \\
\hline & & \multicolumn{2}{|c|}{ Hipertensi } & \multicolumn{2}{|c|}{ Normal } & & \\
\hline & & $\mathrm{F}$ & $\%$ & $\mathrm{f}$ & $\%$ & $\mathrm{~F}$ & $\%$ \\
\hline 1 & Sedang & 50 & 55,6 & 40 & 44,4 & 90 & 100 \\
\hline \multirow[t]{2}{*}{2} & Berat & 18 & 90 & 2 & 10 & 20 & 100 \\
\hline & Jumlah & 68 & 61,8 & 42 & 38,2 & 110 & 100 \\
\hline \multicolumn{8}{|c|}{ Chi-square 0,004 OR 0,1} \\
\hline \multirow{3}{*}{ No } & \multirow{3}{*}{ Jenis Kelamin } & \multicolumn{4}{|c|}{ Tekanan Darah } & \multirow{2}{*}{\multicolumn{2}{|c|}{ Total }} \\
\hline & & & nsi & & & & \\
\hline & & $\mathrm{F}$ & $\%$ & $\mathrm{~F}$ & $\%$ & $\mathrm{~F}$ & $\%$ \\
\hline 1 & Laki - laki & 27 & 77,1 & 8 & 22,9 & 35 & 100 \\
\hline \multirow[t]{3}{*}{2} & Perempuan & 41 & 54,7 & 34 & 43,5 & 75 & 100 \\
\hline & & 68 & 61,8 & 42 & 38,2 & 110 & 100 \\
\hline & \multicolumn{7}{|c|}{ Chi-square 0,002 OR 2,8 } \\
\hline \multirow{3}{*}{ No } & \multirow{3}{*}{ Kecemasan } & \multicolumn{4}{|c|}{ Tekanan Darah } & \multirow{2}{*}{\multicolumn{2}{|c|}{ Total }} \\
\hline & & & nsi & & & & \\
\hline & & $\mathrm{F}$ & $\%$ & $\mathrm{~F}$ & $\%$ & $\mathrm{~F}$ & $\%$ \\
\hline 1 & Cemas & 48 & 64,9 & 26 & 35,1 & 35 & 100 \\
\hline \multirow[t]{2}{*}{2} & Tidak cemas & 20 & 55,6 & 16 & 44,4 & 75 & 100 \\
\hline & Jumlah & 68 & 61,8 & 42 & 38,2 & 110 & 100 \\
\hline \multicolumn{8}{|c|}{ Chi-square 0,346} \\
\hline \multirow{3}{*}{ No } & \multirow{3}{*}{ Riwayat keluarga } & \multicolumn{4}{|c|}{ Tekanan Darah } & \multirow{2}{*}{\multicolumn{2}{|c|}{ Total }} \\
\hline & & & nsi & & & & \\
\hline & & $\mathrm{F}$ & $\%$ & $\mathrm{~F}$ & $\%$ & $\mathrm{~F}$ & $\%$ \\
\hline 1 & $\mathrm{HT}$ & 68 & 98,6 & 1 & 1,4 & 69 & 100 \\
\hline \multirow[t]{3}{*}{2} & Tidak Hipertensi & 0 & 0 & 41 & 100 & 41 & 100 \\
\hline & Jumlah & 68 & 61,8 & 42 & 38,2 & 110 & 100 \\
\hline & & & re 0,0 & & & & \\
\hline
\end{tabular}

Hasil uji statistik dengan chi square untuk beban kerja didapatkan nilai $p$-value $0,004<0,05$ dapat diketahui ada hubungan antara beban kerja dengan tekanan darah. Seseorang dengan beban kerja lebih berat mempunyai peluang 0,1 mengalami hipertensi. Hasil uji chi square untuk jenis kelamin didapatkan niali $p$-value $0,002<0,05$ berarti ada hubungan antara jenis kelamin dengan tekanan darah. Perempuan memiliki risiko 2,8 kali lebih besar mengalami hipertensi. Hasil uji chi square untuk tingkat Kecemasan didapatkan $p$-value 0,463>0,05 berarti tidak hubungan antara tingkat kecemasan dengan peningkatan tekanan darah. Hasil uji chi square untuk riwayat keluarga didapatkan nilai $p$-value $0,000<0,05$ sehingga ada hubungan riwayat keluarga dengan tekanan darah.

\section{Pembahasan}

Penyakit Coronavirus 2019 (Covid-19) adalah penyakit sistemik yang disebabkan oleh Corona Virus 2 (SARS-Cov2) yang menyerang sistem pernapasan. Salah satu faktor risiko yang dapat memperburuk Covid-19 adalah hipertensi (Drager, PioAbreu, Lopes, \& Bortolotto, 2020). Hipertensi adalah peningkatan tekanan darah sistolik $\geq 140 \mathrm{mmHg}$ dan / atau tekanan darah diastolik $\geq 90 \mathrm{mmHg}$ (Singh, Shankar, \& Singh, 2017).

Kasus kejadian COVID-19 di Indonesia sampai sekarang masih terus bertambah dengan tingkat kematian tertinggi di dunia (Handayani, Hadi, Isbaniah, Burhan, \& Agustin, 2020). Hal ini membuat 
masyarakat menjadi khawatir, cemas, bingung hingga stress sehingga mempengaruhi kesehatan (Afifah, 2020). Masyarakat menjadi takut untuk memeriksakan kondisi kesehatannya di rumah sakit, klinik maupun puskesmas dengan alasan takut tertular COVID-19, sehingga banyak penyakit yang tidak terkontrol dengan baik, salah satunya adalah hipertensi. Penelitian ini menggambarkan beberapa faktor yang mempengaruhi terjadinya peningkatan tekanan darah pada masa pandemi COVID19.

Berdasarkan tabel 3 didapatkan beban kerja berat 57 orang, beban kerja sedang 53 orang. Beban kerja yang berlebih pada seseorang menjadi salah satu faktor terjadinya peningkatan tekanan darah. Hal ini disebabkan beban kerja yang berat akan menambah beban tambahan bagi jantung yang harus memompa darah lebih banyak lagi keseluruh tubuh (Purwaningsih \& Aisyah, 2016). Pada siklus kehidupan seseorang tak jarang mengalami stres yang berhubungan dengan pekerjaan mereka. Hal ini dapat dipengaruhi karena tuntutan kerja yang terlalu keras atau seringnya bekerja sampai larut malam. Beban kerja meliputi pembatasan jam kerja selama 6-7 jam, sisanya diharuskan untuk beristirahat untuk memulihkan kondisi kesehatan (Sinubu, Rondonuwu, \& Onibala, 2015). Hal ini sesuai dengan teori bahwa beban kerja yang berat akan mempengaruhi beban kerja jantung dalam memompa.

Selain beban kerja yang berat, faktor lain yang berhubungan dengan peningkatan tekanan darah pada penelitian ini adalah jenis kelamin, yaitu perempuan Dalam penelitian ini sebagian besar perempuan $54,7 \%$ mengalamai tekanan darah tidak normal. Hal ini sesuai dengan penelitian (Supriyono, 2019) bahwa wanita lebih berisiko mengalami peningkatan tekanan darah. Saat awal menstruasi wanita cenderung mengalami penurunan tekanan darah, akan tetapi setelah menapause wanita cenderung mengalami peningkatan tekkanan darah hal ini disebabkan karena faktor hormonal yang dapat mempengaruhinya (Kozier, 2010).

Faktor tingkat kecemasan pada penelitian ini didapatkan bahwa sebagian besar 75 orang tidak mengalami kecemasan, dan 35 orang mengalami kecemasan. Hal ini menunjukkan bahwa tidak ada hubungan yang signifikan dengan peningkatan tekanan darah. Hal ini sesuai dengan penelitian (Pertiwi, 2017) bahwa tidak ada hubungan antara kecemasan dengan peningkatan tekanan darah. Kecemasan dipengaruhi oleh berbagai hal seperti kepercayaan diri, mekanisme koping, tingkat maturitas, tipe epribadian dan ancaman eksternal. Tingkat kepercayaan diri seseorang sangat penting dimana orang yang memiliki kepercayaan diri rendah akan merasa terancam dibandingkan dengan orang yang memiliki kepercayaan diri yang baik. Pada penelitian ini hanya sebatas melihat hubungan kecamasan dengan tekanan darah. Kecemasan yang dirasakan warga selain bidang ekonomi juga bidang pendidikan anak - anak dimana saat ini anak - anak melakukan pembelajaran dirumah lebih lebih dengan tingkat pendidikan yang rendah sehingga para orang tua merasa khawatir tidak mampu mengikti proses pembalajaran anak disekolahnya, sedangkan pada orang tua yang bekerja kecemasannya berbeda. Mereka khawatir akan bosan mendampingi anak - anaknya dirumah. Adanya pandemi ini membuat warga merasa cemas, hal ini disebabkan karena ada kepala keluarga yang harus kehilangan pekerjaannya, selain itu tingkat penghasilan yang turun. Kecemasan yang dirasakan oleh warga tidak hubungan berhubungan dengan peningkatan tekanan darah, hal ini karena usia warga masih banyak usia yang masih produktif sehingga metabolisme tubuh masih seimbang.

Faktor terakhir adalah riwayat penyakit keluarga, berdasarkan tabel 3 didapatkan sebagian besar warga 69 orang yang memiliki riwayat hipertensi. Dari hasil penelitian didapatkan bahwa warga yang memiliki keluarga dengan hipertensi berisiko mengalami peningkatan tekanan darah. Hal ini sesuai dengan penelitian (Supriyono, 2019) bahwa riwayat keluarga dekat meningkatkan resiko hipertensi. Hipertensi memiliki kecenderungan dapat diturunkan pada generasi selanjutnya. Faktor risiko ini tidak dapat dihilangkan tetapi dapat diadaptasi dengan rajin melakukan kontrol tekanan darah (Adam, Nelwan, \& Wariki, 2018). Hal ini bukan 
berarti bahwa semua orang yang memiliki riwayat keluarga dengan hipertensi pasti akan menderita hipertensi. Selain faktor genetik ini, hipertensi bisa juga dipengaruhi oleh faktor-faktor lain. faktor Riwayat keluarga bisa di minimalkan dengan menjaga pola hidup sehat yaitu olah raga, diet, hindari stress.

\section{Kesimpulan}

Berdasarkan hasil penelitian dapat disimpulkan bahwa faktor yang berhubungan dengan tekanan darah adalah jenis kelamin, beban kerja dan riwayat keluarga sedangkan faktor tingkat kecemasan tidak berhubungan dengan kejadian peningkatan tekanan darah pada masa Pandemi COVID-19. Diharapkan masyarakat tidak teralu khawatir untuk rutin memeriksakan tekanan darahnya di pelayanan kesehatan yang tersedia dengan mengikuti protokol kesehatan yang benar.

\section{Referensi}

Adam, Avelia Gustia Anastasya, Nelwan, Jeini Ester, \& Wariki, Windi M. V. (2018). Kejadian Hipertensi dan Riwayat Keluarga Menderita Hipertensi di Puskesmas Paceda Kota Bitung. Jurnal KESMAS, 7(5).

Afifah, Mahardini Nur. (2020). Bagaimana Dampak Stres Pandemi Corona pada Kesehatan Mental dan Fisik?, Kompas.com.

Afriyadi, Achmad Dwi. (2020). Risma Bukabukaan Dampak Corona ke Pengusaha Surabaya, detikFinance. Retrieved from https://finance.detik.com/beritaekonomi-bisnis/d-5028596/rismabuka-bukaan-dampak-corona-kepengusaha-surabaya

Drager, Luciano F., Pio-Abreu, Andrea, Lopes, Renato D., \& Bortolotto, Luiz A. (2020). Is Hypertension a Real Risk Factor for Poor Prognosis in the COVID-19 Pandemic? Current Hypertension Reports, 22(43). doi: doi.org/10.1007/s11906-02001057-x

Fadlilah, Siti, Rahil, Nazwar Hamdani, \& Lanni, Fransiska. (2020). Analisis Faktor Yang Mempengaruhi Tekanan Darah dan Saturasi Oksigen Perifer
(SPO2). Jurnal Kesehatan Kusuma Husada, 11(1), 21-30. doi: doi.org/10.34035/jk.v11i1.408

Handayani, Diah, Hadi, Dwi Rendra, Isbaniah, Fathiyah, Burha, Erlina, \& Agustin, Heidy. (2020). Penyakit Virus Corona 2019. Jurnal Respirologi Indonesia, 40(2).

Hartono, Soesanti Harini. (2020). Hari Hipertensi Dunia : Selama Pandemi Covid-19, Penderita Hipertensi Wajib Rutin Cek Tekanan Darah, Ini Alasannya, GRID HEALTH. Retrieved from https://health.grid.id/read/352158 545/hari-hipertensi-dunia-selamapandemi-covid-19-penderitahipertensi-wajib-rutin-cek-tekanandarah-ini-alasannya?page=all

Kozier. (2010). Buku Ajar Fundamental Keperawatan Konsep, Proses \& Praktik. Jakarta: EGC.

Maier, Wolfgang, Buller, R, Philipp, M, \& Heuser, I. (1988). The Hamilton Anxiety Scale : Reliability, Validity and Sensitivity to Change in Anxiety and Depression Disorders. Journal of Affective Disorders, 14(1), 61-68. doi: 10.1016/0165-0327(88)90072-9

Marzuki, M. Bahrul. (2020). Covid-19 di Surabaya Meningkat Tajam, Layanan Kesehatan Tak Cukup Tampung Pasien, Jatim Times. Retrieved from

https://jatimtimes.com/baca/212922/2020 0417/094900/covid-19-di-surabayameningkat-tajam-layanankesehatan-tak-cukup-tampungpasien

Notoatmodjo, Soekidjo. (2012). Metodologi Penelitian Kesehatan. Jakarta: Rineka Cipta.

Pertiwi, Gracia Herni. (2017). Hubungan Tekanan Darah Dengan Tingkat Kecemasan Pada Lansia Santa Angela Di Samarinda. Media Sains, 10(1), 21-27.

Pranita, Ellyvon. (2020). Diumumkan Awal Maret , Ahli : Virus Corona Masuk Indonesia dari Januari, Kompas.com. Retrieved from https://www.kompas.com/sains/re $\mathrm{ad} / 2020 / 05 / 11 / 130600623 /$ diumu mkan-awal-maret-ahli--virus-coronamasuk-indonesia-dari-januari

Purwaningsih, Ratna, \& Aisyah. (2016). Analisis Pengaruh Temperatur Lingkungan, Berat Badan dan 
Tingkat Beban Kerja Terhadap Denyut Nadi Pekerja Ground Handling Bandara. Jurnal Teknik Industri, XI(1).

Rohkuswara, Teguh Dhika, \& Syarif, Syahrizal. (2017). Hubungan Obesitas dengan Kejadian Hipertensi Derajat 1 di Pos Pembinaan Terpadu Penyakit Tidak Menular (Posbindu PTM) Kantor Kesehatan Pelabuhan Bandung Tahun 2016. Jurnal Epidemiologi Kesehatan Indonesia, 1(2).

Sasmalinda, Lusi, Syafriandi, \& Helma. (2013). Faktor-faktor yang Mempengaruhi Perubahan Tekana Darah Pasien di Puskesmas Malalo Batipuh Selatan dengan Menggunakan Regresi Linier Berganda. UNP JOURNAL OF MATHEMATICS, 2(1).

Singh, Shikha, Shankar, Ravi, \& Singh, Gyan Prakash. (2017). Prevalence and Associated Risk Factors of Hypertension : A Cross-Sectional Study in Urban Varanasi. International Journal of Hypertension. doi: doi.org/10.1155/2017/5491838

Sinubu, Risky Brian, Rondonuwu, Rolly, \& Onibala, Franly. (2015). Hubungan Beban Kerja dengan Kejadian Hipertensi Pada Tenaga Pengajar di SMA 1 Amurang Kabupaten Minahasa Selatan. e-Journal Keperawatan, 3(2).

Suprayitno, E. (2019). Gambaran Status Tekanan Darah Penderita Hipertensi di Desa Karanganyar Kecamatan Kalianget Kabupaten Sumenep. Journal Of Health Science (Jurnal Ilmu Kesehatan), 4(2), 20-24. https://doi.org/10.24929/jik.v4i2.7 99

Suprayitno, E, \& Wahid, A. (2019). Pendampingan Tentang Penyakit Hipertensi Dan Perawatan Keluarga Dengan Hipertensi. Seminar Nasional Hasil Pengabdian ..., 104106.

http://proceeding.uim.ac.id/index.p $\mathrm{hp} /$ senias/article/view/299

Suprayitno, E, \& Huzaimah, N. (2020). PENDAMPINGAN LANSIA DALAM PENCEGAHAN KOMPLIKASI HIPERTENSI. SELAPARANG Jurnal Pengabdian Masyarakat Berkemajuan, 4(1), 518-521.

Supriyono. (2019). Analisis Faktor-faktor yang Berhubungan Tekanan Darah
Sistole pada Peserta Pelatihan Manajemen Puskesmas. Jurnal Inspirasi, $\quad 10(1), \quad 32-48 . \quad$ doi: 10.35880/inspirasi.v10i1.62 